\title{
The glycosylation landscape of pancreatic cancer (Review)
}

\author{
JENNIFER MUNKLEY \\ Institute of Genetic Medicine, Newcastle University, International Centre for Life, Newcastle upon Tyne NE1 3BZ, UK
}

Received August 31, 2018; Accepted December 20, 2018

DOI: $10.3892 / \mathrm{ol} .2019 .9885$

\begin{abstract}
Pancreatic adenocarcinoma is a lethal disease with a 5-year survival rate of $<5 \%$, the lowest of all types of cancer. The diagnosis of pancreatic cancer relies on imaging and tissue biopsy, and the only curative therapy is complete surgical resection. Pancreatic cancer has the propensity to metastasise at an early stage and the majority of patients are diagnosed when surgery is no longer an option. Hence, there is an urgent need to identify biomarkers to enable early diagnosis, and to develop new therapeutic strategies. One approach for this involves targeting cancer-associated glycans. The most widely used serological marker in pancreatic cancer is the carbohydrate antigen CA 19-9 which contains a glycan known as sialyl Lewis A (sLe ${ }^{\mathrm{A}}$ ). The CA 19-9 assay is used routinely to monitor response to treatment, but concerns have been raised about its sensitivity and specificity as a diagnostic biomarker. In addition to $\mathrm{sLe}^{\mathrm{A}}$, a wide range of alterations to other important glycans have been observed in pancreatic cancer. These include increases in the sialyl Lewis $X$ antigen $\left(\mathrm{sLe}^{\mathrm{x}}\right)$, an increase in truncated O-glycans (Tn and sTn), increased branched and fucosylated $\mathrm{N}$-glycans, upregulation of specific proteoglycans and galectins, and increased O-GlcNAcylation. Growing evidence supports crucial roles for glycans in all stages of cancer progression, and it is well established that glycans regulate tumour proliferation, invasion and metastasis. The present review describes the biological significance of glycans in pancreatic cancer, and discusses the clinical value of exploiting aberrant glycosylation to improve the diagnosis and treatment of this deadly disease.
\end{abstract}

\section{Contents}

1. Introduction

2. Aberrant glycosylation in pancreatic cancer

3. The Sialyl Lewis antigens $\left(\mathrm{sLe}^{\mathrm{A}}\right.$ and $\left.\mathrm{sLe}^{\mathrm{X}}\right)$

Correspondence to: Dr Jennifer Munkley, Institute of Genetic Medicine, Newcastle University, International Centre for Life, Central Parkway, Newcastle upon Tyne NE1 3BZ, UK

E-mail: jennifer.munkley@ncl.ac.uk

Key words: glycosylation, glycans, pancreatic cancer, treatment, biomarkers

\author{
4. Truncated O-glycans \\ 5. N-glycans \\ 6. The HBP pathway \\ 7. Proteoglycans \\ 8. Galectins \\ 9. Conclusions and future perspectives
}

\section{Introduction}

Pancreatic adenocarcinoma is one of the worlds' most aggressive malignancies with a five year survival rate of less than $5 \%$, the worst prognosis among all cancers (1). The poor survival rate is mostly due to the lack of a reliable early detection method, a tendency to metastasise at an early stage and resistance to available therapeutic options $(2,3)$. In addition, there is often an absence of symptoms in early disease and established disease can have clinical similarities to benign conditions, making it difficult to diagnose (4). The diagnosis of pancreatic cancer relies on imaging and tissue biopsy, and the only curative therapy is complete surgical resection. Non-invasive biomarkers, such as those from serum, could provide a useful complement to imaging and cytology diagnostic methods and have the potential to aid clinical decisions as part of a routine blood test. Currently, the only clinical biomarker used in the management of pancreatic cancer is the serum marker CA19-9, which although used widely for disease monitoring, does not provide adequate accuracy for early detection and diagnosis. Given the usually late diagnosis of pancreatic cancer, highly specific circulating biomarkers for cancer detection and screening are urgently needed, and would be a major breakthrough allowing treatment for more patients.

Glycosylation is an enzymatic process that links glycan sugars to other glyans, lipids or proteins. Glycosylation takes place in the Golgi apparatus and endoplasmic reticulum and occurs as the consequence of the synchronised action of glycosylation enzymes. The two most common mechanisms by which glycans can be linked to lipids and proteins are O-linked and $\mathrm{N}$-linked glycosylation. In O-linked glycosylation glycans are added sequentially to the hydroxyl oxygen of serine/threonine residues on target proteins and extended to produce various core and terminal structures that can be sialylated and/or fucosylated. In N-linked glycosylation 14 sugar preassembled blocks are transferred co-translationally to the amide group of an asparagine residue. $\mathrm{N}$-glycans contain a common pentasaccharide core region consisting of three mannose and two $\mathrm{N}$-acetylglucosamine (GlcNAc) subunits. This can be further 
modified by the addition of terminal Gal (galactose), GlcNAc, fucose and sialic acid moieties.

Aberrant glycosylation in cancer was first described nearly 50 years ago (5), and since then it has been well documented that the development and progression of cancer results in fundamental changes in the glycosylation patterns of cell surface and secreted glycoproteins (6). Many of the first cancer-specific antibodies identified were directed against oncofetal antigens expressed on embryonic and tumour cells but not in adult tissues (7) and growing evidence supports crucial roles for glycans during all steps of tumour progression. Glycans can regulate tumour proliferation, invasion, metastasis and angiogenesis (8), and aberrant glycosylation has been proposed as a general hallmark of all cancers (6).

Glycans can control cell identity and cell environment interactions. Changes in the glycosylation modification of proteins that are expressed on the cell surface, or secreted by cancer cells, are promising sources of potential biomarkers $(9,10)$. Glycoconjugates with altered glycosylation are often shed into the circulation, allowing the distinction between patients with and without cancer (11-13). Recent research has uncovered new ways that glycosylation can contribute to cancer biology, as well as new strategies to improve treatment by exploiting glycans (14). This review discusses the changes in glycosylation involved in pancreatic cancer, their role in disease development and progression, and the huge potential to exploit glycans to improve diagnosis and treatment.

\section{Aberrant glycosylation in pancreatic cancer}

In the normal pancreas glycosylated proteins have important functions, including protection and lubrication of the pancreatic ducts (15). In pancreatic cancer glycosylation of proteins becomes deregulated, and the aberrant expression of specific glycans is associated with disease progression and poor prognosis. Changes to the glycome in pancreatic cancer include increases in the sialyl Lewis antigens $\left(\mathrm{sLe}^{\mathrm{A}}\right.$ and $\mathrm{sLe}^{\mathrm{x}}$ ), an increase in truncated O-glycans (Tn and $\mathrm{sTn}$ ), increased branched and fucosylated $\mathrm{N}$-glycans, upregulation of specific proteoglycans and galectins, and increased O-GlcNAcylation (some of these alterations are summarised in Fig. 1 and Table I).

\section{The Sialyl Lewis antigens (sLe ${ }^{A}$ and $s L e^{\mathrm{X}}$ )}

The most widely used serological assay used in the management of pancreatic cancer detects a cancer associated carbohydrate antigen, called CA 19-9, that contains a glycan known as sialyl Lewis A $\left(\mathrm{sLe}^{\mathrm{A}}\right)(16-20)$. $\mathrm{sLe}^{\mathrm{A}}$ is part of the Lewis family of blood group antigens, named after the discoverer of a series of antigens found on red blood cells. Studies have shown that $\mathrm{SLe}^{\mathrm{A}}$ is found at low levels in normal tissue, higher levels in embryonic tissue (21), and is overexpressed in epithelial cancers (22). In the normal pancreas $s L e^{\mathrm{A}}$ is found on the epithelial surfaces of the ducts, whereas in pancreatic cancer sLe ${ }^{\mathrm{A}}$ can be heavily secreted into the lumen of proliferating ducts and pass into the bloodstream (23).

The CA 19-9 assay detects the sLe ${ }^{\mathrm{A}}$ glycan motif, along with the additional glycans, lipids and proteins to which it is attached. $\mathrm{sLe}^{\mathrm{A}}$ has been found on numerous proteins including mucins, carcinoembryonic antigen and circulating apolipoproteins (24). The CA 19-9 assay is widely used to monitor response to treatment in patients already diagnosed with pancreatic cancer $(25,26)$, but concerns have been raised about its sensitivity and specificity as a diagnostic biomarker, and it is not used in screening (22,27-29). Mucin glycoproteins have multiple roles in pancreatic cancer and are major carriers of glycans including CA 19-9 (15). Altered mucin glycoforms have been observed in both the early stages of pancreatic cancer, and in late stage metastatic disease (30). It has been suggested that measuring the CA19-9 antigen on specific protein carriers (such as mucins), and detecting additional related glycans may improve the performance of the CA19-9 assay $(28,31,32)$. Targeting mucin glycosylation may also limit pancreatic cancer growth (33).

In addition to $\mathrm{sLe}^{\mathrm{A}}$, other members of the Lewis antigens also have roles in pancreatic cancer. An isomer of $s \mathrm{Le}^{\mathrm{A}}$ (known as sialyl Lewis $\mathrm{X}\left(\mathrm{sLe}^{\mathrm{X}}\right)$ ) is also upregulated in some pancreatic cancers, and can be detected in the blood of many patients (34-37). The sialyl Lewis antigens are the minimal recognition motif for ligands of selectins, a family of lectins with roles in leukocyte trafficking with roles in tumour extravasation and cancer metastasis (38). In pancreatic cancer $\mathrm{sLe}^{\mathrm{X}}$ has been found on migrating lymphocytes and linked to invasion (39). Increased sLe ${ }^{\mathrm{X}}$ antigen on the glycoprotein ceruloplasmin has been described in pancreatic malignancy (37), and numerous proteins implicated in pancreatic cancer (including Kras, SPARC and Wnt7b) have been found to express sLe ${ }^{\mathrm{x}}$ glycans (40). Tang et al (2016) profiled the levels of multiple glycans in in the plasma of 200 patients with either benign pancreatic disease or pancreatic cancer (32), and showed increased levels of CA19-9, $\mathrm{sLe}^{\mathrm{X}}$ and also in sialylated type 1 LacNAc (also known as Dupan-2). Dupan-2 has previously been associated with pancreatic cancer and is increased in some patients $(41,42)$. Each of the three glycans (CA19-9, $\mathrm{sLe}^{\mathrm{X}}$ and Dupan-2) are increased in some pancreatic cancer patients but not in others, leading the authors to suggest the use of a three glycan panel to improve diagnosis and facilitate pancreatic cancer sub-classification (32).

\section{Truncated O-glycans}

Immature, truncated O-glycans are characteristic of virtually all epithelial cancer cells (43). In pancreatic cancer, the expression of the truncated cancer-associated O-glycans $\mathrm{Tn}$ and sialyl-Tn (sTn) are linked to poor patient outcome (11), and associated with cancer cell growth and metastasis $(44,45)$. The normal pancreas does not express Tn or sTn (46), but levels are high in pancreatic cancer $(30,45)$. Specifically, truncated $\mathrm{O}$-glycans have been detected on Nucleolin, EGFR and Her2 $(45,47)$. COSMC is a molecular chaperone that is essential for correct protein O-glycosylation (48). Knockdown of COSMC promotes aberrant O-glycosylation in pancreatic cancer, and this is linked to anti-apoptotic and pro-metastatic cell behaviour, reduced proliferation and increased migration (45). In addition to COSMC, the GALNT3 enzyme is also linked to the aberrant production of tumor-associated O-glycans in pancreatic cancer. GALNT3 is increased in well/moderately differentiated pancreatic cancer, but lost in poorly differentiated tissues $(47,49)$. 

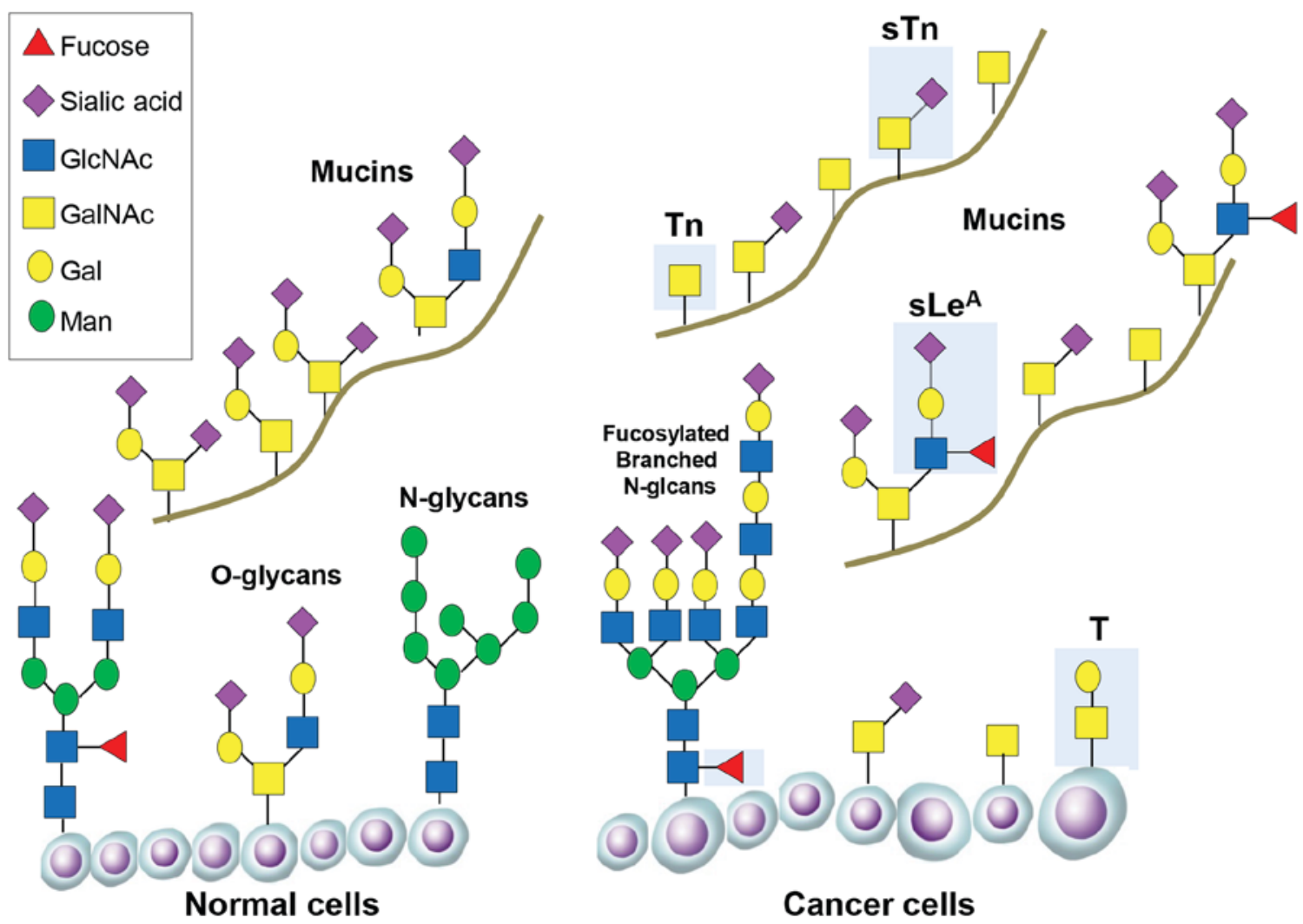

Figure 1. Changes in glycosylation during cancer progression. Representative O-glycans and N-glycans are shown attached on the surface of normal cells and cancer cells. O-glycans are also shown attached to mucin glycoproteins. Important tumour-associated glycans are shown in the blue boxes, including truncated O-glycans (Tn and sTn) and fucosylated branched N-glycans $\left(\mathrm{sLe}^{\mathrm{A}}\right.$ and SLe ${ }^{\mathrm{X}}$ ). For more information about the structure of each glycan see Table I.

\section{N-glycans}

Aberrant N-linked glycosylation is common in pancreatic cancer. In particular, pancreatic cancer cells frequently display increased levels of highly branched $\mathrm{N}$-glycans, and alterations to $\mathrm{N}$-glvcan sialylation or fucosylation. Increased levels of $\mathrm{N}$-glycosylation has been found on integrins and ECM adhesion proteins (50) and in proteins involved in pathways important in pancreatic cancer such as TGF- $\beta$, TNF, and NF-kappa-B signalling (51). N-glycosylation can also influence the surface expression of receptor tyrosine kinases and enhance the chemosensitivity of drug resistant pancreatic cancer cells (52). $\mathrm{N}$-glycans have shown promise as biomarkers in pancreatic cancer. The sialyltransferase enzymes ST6Gall and ST3Gal3 are overexpressed in pancreatic tissue and this is linked to invasive potential (53-55). It is also possible to detect changes to $\mathrm{N}$-glycans in patient blood. Increased fucosylation can be detected in serum from patients with pancreatic cancer (56), and highly branched $\mathrm{N}$-glycans are increased in the blood of patients with aggressive disease $(57,58)$. Fucosylated epitopes occur on specific proteins such as haptoglobin and ribonuclease 1 (RNASE1) and these are currently being explored for use diagnostically $(59,60)$.

\section{The HBP pathway}

The hexosamine biosynthetic pathway (HBP) produces the amino sugar conjugate $\mathrm{O}$-linked $\mathrm{N}$-acetylglucosamine (O-GlcNAc). Addition of O-GlcNAc to proteins (known as O-GlcNAcylation) can alter key hallmarks of cancer including transcription, cell signalling metabolism and epigenetics $(61,62)$, and may impact cell survival and resistance during chemotherapy (63). O-GlcNAc is added to and removed from proteins by the O-GlcNAc cycling enzymes OGT and OGA. Both these enzymes are dramatically elevated in pancreatic cancer relative to normal pancreas, as are the overall levels of protein O-GlcNAcylation (64). In the normal pancreas OGT allows cells to dynamically respond to glucose levels by modulating O-linked protein glycosylation (65). When pancreatic cancer develops increased O-GlcNAcylation may block cancer cell apoptosis and lead to oncogenic activation of NF-kB signalling (66). Several proteins with defined roles in pancreatic cancer have been shown to be modified by O-GlcNAc including the heat shock protein HSP70 (67), the transcription factor Sp1 (68), the Wnt signalling proteins $\beta$-catenin and LRP6 (69), and more recently the transcription factor Sox 2 that determines self-renewal in pancreatic cancer and is responsible for tumour initiation (70). Inhibiting O-GlcNAcylation can reduce pancreatic tumour growth and progression suggesting HBP is promising potential therapeutic target $(66,71,72)$.

\section{Proteoglycans}

In addition to aberrant protein glycosylation, cancer cells can also have alterations in proteoglycans (73). Proteoglycans are heavily glycosylated glycoproteins with attached glycosaminoglycans (GAGs) such as chondroitin sulphate and heparin 
Table I. Summary of glycan alterations in pancreatic cancer.

\begin{tabular}{|c|c|c|c|}
\hline Glycan & Structure & Change & (Refs.) \\
\hline \multirow[t]{3}{*}{ sialyl Lewis A (sLeA) } & & Upregulated & (23) \\
\hline & & Detected by CA $19-9$ assay & $(16-20)$ \\
\hline & R & $\begin{array}{l}\text { Found on various protein carriers } \\
\text { including mucins }\end{array}$ & $(15,28,31,32)$ \\
\hline \multirow[t]{3}{*}{ sialyl Lewis X (sLex) } & & Upregulated & $(34-37)$ \\
\hline & & Linked to invasion & (39) \\
\hline & & $\begin{array}{l}\text { Found on numerous proteins implicated in } \\
\text { pancreatic cancer }\end{array}$ & $(32,40-42)$ \\
\hline \multirow[t]{2}{*}{ Tn antigen } & Tn & Increased & $(30,45)$ \\
\hline & seerThr & Linked to poor prognosis \& metastasis & $(11,44,45)$ \\
\hline \multirow[t]{2}{*}{ sTn antigen } & sTn & Increased & $(30,45)$ \\
\hline & & Linked to poor prognosis \& metastasis & $(11,44,45)$ \\
\hline \multirow[t]{3}{*}{ Fucosylated \& branched N-glycans } & $=$ & $\begin{array}{l}\text { Highly branched } \mathrm{N} \text {-glycans increased in } \\
\text { aggressive disease }\end{array}$ & $(57,58)$ \\
\hline & & Increased fucosylation & $(56,59,60)$ \\
\hline & the & $\begin{array}{l}\text { Found on numerous proteins implicated } \\
\text { in pancreatic cancer }\end{array}$ & $(50-52)$ \\
\hline \multirow[t]{2}{*}{ O-GlcNAcylation } & O.GICNAC & Increased & (64) \\
\hline & & $\begin{array}{l}\text { Inhibition can reduce tumour growth } \\
\text { and progression }\end{array}$ & $(66,71,72)$ \\
\hline \multirow[t]{2}{*}{ Proteoglycans } & & $\begin{array}{l}\text { Numerous proteoglycans are overexpressed } \\
\text { in pancreatic cancer }\end{array}$ & $(74-82)$ \\
\hline & 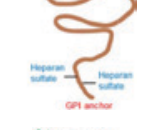 & $\begin{array}{l}\text { e.g., the heparin sulphate proteoglycan } \\
\text { glypican-1 is linked to disease progression } \\
\text { and expressed by exosomes }\end{array}$ & $(83,84)$ \\
\hline Galectins & $\begin{array}{l}\text { Woalectin } 11 \\
\text { J Galectin } 3 \\
\end{array}$ & Galectin-1 \& Galectin-3 overexpressed & $(87-90)$ \\
\hline
\end{tabular}

sulphate that are located on the cell surface or secreted. Numerous proteoglycans have been found to be overexpressed in pancreatic cancer, including syndecan-1, versican, decorin, lumican and biglycan (74-81). Of particular interest, the heparin sulphate proteoglycan glypican-1 is overexpressed in pancreatic cancer cell models and patient tumours (82) and has been shown to contribute to pancreatic cancer progression using mouse models $(83,84)$. A recent study found that glypican-1 is specifically expressed by circulating cancer exosomes, and may serve as non-invasive diagnostic and screening tool to enable early diagnosis of pancreatic cancer (85).

\section{Galectins}

As well as changes in glycosylation patterns cancer cells may also display altered expression of proteins that interact with glycans. An important example of such proteins is the galectins, which are a group of glycan binding proteins with an established role in cancer biology (86). In pancreatic cancer, Galectin-1 (GAL1) and Galectin-3 (GAL3) are overexpressed (87-90). This is important for cancer progression since GAL1 can induce stroma remodelling, tumour cell proliferation, invasion, angiogenesis, inflammation, and metastasis $(91,92)$, and GAL3 can activate pancreatic cancer cells to produce inflammatory cytokines (88). It is likely that galectin specific targeting will have a broad therapeutic potential in pancreatic cancer, either alone or in combination with other therapies $(88,93)$.

\section{Conclusions and future perspectives}

The survival rates for pancreatic cancer have remained dismal for many years, and as such there is an urgent need to improve diagnosis and treatment. A wide range of alterations to glycans have been detected in pancreatic cancer, and these show promise as both potential circulating biomarkers and as targets for glycan specific therapies. The expression of specific glycans within pancreatic tumours, their presence in patient serum, and their possible ability to facilitate metastases, suggests glycans could help guide precision medicine strategies. Recent profiling has defined 4 molecular subtypes of pancreatic cancer (94), and it likely that diversity exists between pancreatic cancers in the variety and type of glycans made and secreted into the blood (24). To fully exploit glycans clinically it will be vital to fully profile the pancreatic cancer glycome and determine how this varies between different tumour types.

\section{Acknowledgements}

Not applicable. 


\section{Funding}

Not applicable.

\section{Availability of data and materials}

Not applicable.

\section{Authors' contributions}

$\mathrm{JM}$ conceived the review, researched the literature and wrote the manuscript.

\section{Ethics approval and consent to participate}

Not applicable.

\section{Patient consent for publication}

Not applicable.

\section{Competing interests}

The author declares that there are no competing interests.

\section{References}

1. Siegel RL, Miller KD and Jemal A: Cancer statistics, 2018. CA Cancer J Clin 68: 7-30, 2018

2. Garrido-Laguna I and Hidalgo M: Pancreatic cancer: From state-of-the-art treatments to promising novel therapies. Nat Rev Clin Oncol 12: 319-334, 2015.

3. Maitra A and Hruban RH: Pancreatic cancer. Annu Rev Pathol 3: 157-188, 2008

4. Klöppel G and Adsay NV: Chronic pancreatitis and the differential diagnosis versus pancreatic cancer. Arch Pathol Lab Med 133: 382-387, 2009

5. Meezan E, Wu HC, Black PH and Robbins PW: Comparative studies on the carbohydrate-containing membrane components of normal and virus-transformed mouse fibroblasts. II. Separation of glycoproteins and glycopeptides by sephadex chromatography. Biochemistry 8: 2518-2524, 1969.

6. Munkley J and Elliott DJ: Hallmarks of glycosylation in cancer. Oncotarget 7: 35478-35489, 2016.

7. Feizi T: Demonstration by monoclonal antibodies that carbohydrate structures of glycoproteins and glycolipids are onco-developmental antigens. Nature 314: 53-57, 1985.

8. Pinho SS and Reis CA: Glycosylation in cancer: Mechanisms and clinical implications. Nat Rev Cancer 15: 540-555, 2015.

9. Kailemia MJ, Park D and Lebrilla CB: Glycans and glycoproteins as specific biomarkers for cancer. Anal Bioanal Chem 409: 395-410, 2017

10. Munkley J: Glycosylation is a global target for androgen control in prostate cancer cells. Endocr Relat Cancer 24: R49-R64, 2017.

11. Mereiter S, Balmaña M, Gomes J, Magalhães A and Reis CA: Glycomic approaches for the discovery of targets in gastrointestinal cancer. Front Oncol 6: 55, 2016.

12. Adamczyk B, Tharmalingam T and Rudd PM: Glycans as cancer biomarkers. Biochim Biophys Acta 1820: 1347-1353, 2012.

13. Munkley J, Vodak D, Livermore KE, James K, Wilson BT, Knight B, Mccullagh P, Mcgrath J, Crundwell M, Harries LW, et al: Glycosylation is an androgen-regulated process essential for prostate cancer cell viability. EBioMedicine 8: 103-116, 2016.

14. Munkley J, Mills IG and Elliott DJ: The role of glycans in the development and progression of prostate cancer. Nat Rev Urol 13 324-333, 2016

15. Moniaux N, Andrianifahanana M, Brand RE and Batra SK Multiple roles of mucins in pancreatic cancer, a lethal and challenging malignancy. Br J Cancer 91: 1633-1638, 2004.
16. Magnani JL, Nilsson B, Brockhaus M, Zopf D, Steplewski Z, Koprowski H and Ginsburg V: A monoclonal antibody-defined antigen associated with gastrointestinal cancer is a ganglioside containing sialylated lacto-N-fucopentaose II. J Biol Chem 257: $14365-14369,1982$.

17. Magnani JL, Brockhaus M, Smith DF, Ginsburg V, Blaszczyk M, Mitchell KF, Steplewski Z and Koprowski H: A monosialoganglioside is a monoclonal antibody-defined antigen of colon carcinoma. Science 212: 55-56, 1981.

18. Herlyn M, Sears HF, Steplewski Z and Koprowski H: Monoclonal antibody detection of a circulating tumor-associated antigen. I. Presence of antigen in sera of patients with colorectal, gastric, and pancreatic carcinoma. J Clin Immunol 2: 135-140, 1982.

19. Magnani JL, Steplewski Z, Koprowski H and Ginsburg V: Identification of the gastrointestinal and pancreatic cancer-associated antigen detected by monoclonal antibody 19-9 in the sera of patients as a mucin. Cancer Res 43: 5489-5492, 1983.

20. Yue T, Partyka K, Maupin KA, Hurley M, Andrews P, Kaul K, Moser AJ, Zeh H, Brand RE and Haab BB: Identification of blood-protein carriers of the CA 19-9 antigen and characterization of prevalence in pancreatic diseases. Proteomics 11: 3665-3674, 2011.

21. Lahdenne P, Pitkänen S, Rajantie J, Kuusela P, Siimes MA, Lanning M and Heikinheimo M: Tumor markers CA 125 and CA 19-9 in cord blood and during infancy: Developmental changes and use in pediatric germ cell tumors. Pediatr Res 38: 797-801, 1995.

22. Goonetilleke KS and Siriwardena AK: Systematic review of carbohydrate antigen (CA 19-9) as a biochemical marker in the diagnosis of pancreatic cancer. Eur J Surg Oncol 33: 266-270, 2007.

23. Kalthoff H, Kreiker C, Schmiegel WH, Greten H and Thiele HG: Characterization of CA $19-9$ bearing mucins as physiological exocrine pancreatic secretion products. Cancer Res 46: 3605-3607, 1986

24. Tang H, Hsueh P, Kletter D, Bern M and Haab B: The detection and discovery of glycan motifs in biological samples using lectins and antibodies: New methods and opportunities. Adv Cancer Res 126: 167-202, 2015.

25. Shah UA and Saif MW: Tumor markers in pancreatic cancer: 2013. JOP 14: 318-321, 2013.

26. Barton JG, Bois JP, Sarr MG, Wood CM, Qin R, Thomsen KM, Kendrick ML and Farnell MB: Predictive and prognostic value of CA 19-9 in resected pancreatic adenocarcinoma. J Gastrointest Surg 13: 2050-2058, 2009.

27. Galli C, Basso D and Plebani M: CA 19-9: Handle with care. Clin Chem Lab Med 51: 1369-1383, 2013.

28. Yue T, Maupin KA, Fallon B, Li L, Partyka K, Anderson MA, Brenner DE, Kaul K, Zeh H, Moser AJ, et al: Enhanced discrimination of malignant from benign pancreatic disease by measuring the CA 19-9 antigen on specific protein carriers. PLoS One 6: e29180, 2011

29. Tempero MA, Uchida E, Takasaki H, Burnett DA, Steplewski Z and Pour PM: Relationship of carbohydrate antigen 19-9 and Lewis antigens in pancreatic cancer. Cancer Res 47: 5501-5503, 1987.

30. Remmers N, Anderson JM, Linde EM, DiMaio DJ, Lazenby AJ, Wandall HH, Mandel U, Clausen H, Yu F and Hollingsworth MA: Aberrant expression of mucin core proteins and o-linked glycans associated with progression of pancreatic cancer. Clin Cancer Res 19: 1981-1993, 2013.

31. Partyka K, Maupin KA, Brand RE and Haab BB: Diverse monoclonal antibodies against the CA 19-9 antigen show variation in binding specificity with consequences for clinical interpretation. Proteomics 12: 2212-2220, 2012.

32. Tang H, Partyka K, Hsueh P, Sinha JY, Kletter D, Zeh H, Huang Y, Brand RE and Haab BB: Glycans related to the CA19-9 antigen are elevated in distinct subsets of pancreatic cancers and improve diagnostic accuracy over CA19-9. Cell Mol Gastroenterol Hepatol 2: 201-221.e215, 2016.

33. Xu HL, Zhao X, Zhang KM, Tang W and Kokudo N: Inhibition of KL-6/MUC1 glycosylation limits aggressive progression of pancreatic cancer. World J Gastroenterol 20: 12171-12181, 2014.

34. Pour PM, Tempero MM, Takasaki H, Uchida E, Takiyama Y, Burnett DA and Steplewski Z: Expression of blood group-related antigens $\mathrm{ABH}$, Lewis A, Lewis B, Lewis X, Lewis Y, and CA 19-9 in pancreatic cancer cells in comparison with the patient's blood group type. Cancer Res 48: 5422-5426, 1988. 
35. Singh S, Pal K, Yadav J, Tang H, Partyka K, Kletter D, Hsueh P, Ensink E, Kc B, Hostetter G, et al: Upregulation of glycans containing 3 ' fucose in a subset of pancreatic cancers uncovered using fusion-tagged lectins. J Proteome Res 14: 2594-2605, 2015 .

36. Tang H, Singh S, Partyka K, Kletter D, Hsueh P, Yadav J, Ensink E, Bern M, Hostetter G, Hartman D, et al: Glycan motif profiling reveals plasma sialyl-lewis $\mathrm{x}$ elevations in pancreatic cancers that are negative for sialyl-lewis A. Mol Cell Proteomics 14: 1323-1333, 2015.

37. Balmaña M, Sarrats A, Llop E, Barrabés S, Saldova R, Ferri MJ, Figueras J, Fort E, de Llorens R, Rudd PM and Peracaula R: Identification of potential pancreatic cancer serum markers: Increased sialyl-Lewis X on ceruloplasmin. Clin Chim Acta 442: 56-62, 2015.

38. Natoni A, Macauley MS and O'Dwyer ME: Targeting selectins and their ligands in cancer. Front Oncol 6: 93, 2016.

39. Takahashi S, Oda T, Hasebe T, Sasaki S, Kinoshita T, Konishi M, Ueda T, Nakahashi C, Ochiai T and Ochiai A: Overexpression of sialyl Lewis $\mathrm{x}$ antigen is associated with formation of extratumoral venous invasion and predicts postoperative development of massive hepatic metastasis in cases with pancreatic ductal adenocarcinoma. Pathobiology 69: 127-135, 2001.

40. Rho JH, Mead JR, Wright WS, Brenner DE, Stave JW, Gildersleeve JC and Lampe PD: Discovery of sialyl Lewis A and Lewis X modified protein cancer biomarkers using high density antibody arrays. J Proteomics 96: 291-299, 2014.

41. Metzgar RS, Gaillard MT, Levine SJ, Tuck FL, Bossen EH and Borowitz MJ: Antigens of human pancreatic adenocarcinoma cells defined by murine monoclonal antibodies. Cancer Res 42 : 601-608, 1982.

42. Kawa S, Tokoo M, Oguchi H, Furuta S, Homma T, Hasegawa Y, Ogata $\mathrm{H}$ and Sakata K: Epitope analysis of SPan-1 and DUPAN-2 using synthesized glycoconjugates sialyllact-N-fucopentaose II and sialyllact-N-tetraose. Pancreas 9: 692-697, 1994.

43. Munkley J: The role of Sialyl-Tn in cancer. Int J Mol Sci 17: 275, 2016.

44. Radhakrishnan P, Dabelsteen S, Madsen FB, Francavilla C, Kopp KL, Steentoft C, Vakhrushev SY, Olsen JV, Hansen L, Bennett EP, et al: Immature truncated O-glycophenotype of cancer directly induces oncogenic features. Proc Natl Acad Sci USA 111: E4066-E4075, 2014.

45. Hofmann BT, Schlüter L, Lange P, Mercanoglu B, Ewald F, Fölster A, Picksak AS, Harder S, El Gammal AT, Grupp K, et al: COSMC knockdown mediated aberrant O-glycosylation promotes oncogenic properties in pancreatic cancer. Mol Cancer 14: 109, 2015.

46. Itzkowitz S, Kjeldsen T, Friera A, Hakomori S, Yang US and Kim YS: Expression of Tn, sialosyl Tn, and T antigens in human pancreas. Gastroenterology 100: 1691-1700, 1991.

47. Chugh S, Meza J, Sheinin YM, Ponnusamy MP and Batra SK Loss of $\mathrm{N}$-acetylgalactosaminyltransferase 3 in poorly differentiated pancreatic cancer: Augmented aggressiveness and aberrant ErbB family glycosylation. Br J Cancer 114: 1376-1386, 2016.

48. Wang Y, Ju T, Ding X, Xia B, Wang W, Xia L, He M and Cummings RD: Cosmc is an essential chaperone for correct protein O-glycosylation. Proc Natl Acad Sci USA 107: 9228-9233, 2010.

49. Taniuchi K, Cerny RL, Tanouchi A, Kohno K, Kotani N, Honke K, Saibara T and Hollingsworth MA: Overexpression of GalNAc-transferase GalNAc-T3 promotes pancreatic cancer cell growth. Oncogene 30: 4843-4854, 2011.

50. Pan S, Tamura Y, Chen R, May D, McIntosh MW and Brentnall TA: Large-scale quantitative glycoproteomics analysis of site-specific glycosylation occupancy. Mol Biosyst 8: 2850-2856, 2012 .

51. Pan S, Chen R, Tamura Y, Crispin DA, Lai LA, May DH, McIntosh MW, Goodlett DR and Brentnall TA: Quantitative glycoproteomics analysis reveals changes in $\mathrm{N}$-glycosylation level associated with pancreatic ductal adenocarcinoma. J Proteome Res 13: 1293-1306, 2014.

52. Contessa JN, Bhojani MS, Freeze HH, Rehemtulla A and Lawrence TS: Inhibition of N-linked glycosylation disrupts receptor tyrosine kinase signaling in tumor cells. Cancer Res 68 3803-3809, 2008.

53. Pérez-Garay $M$, Arteta $B$, Llop E, Cobler L, Pagès L, Ortiz R, Ferri MJ, de Bolós C, Figueras J, de Llorens R, et al: $\alpha 2,3$-Sialyltransferase ST3Gal IV promotes migration and metastasis in pancreatic adenocarcinoma cells and tends to be highly expressed in pancreatic adenocarcinoma tissues. Int $\mathrm{J}$ Biochem Cell Biol 45: 1748-1757, 2013.
54. Pérez-Garay M, Arteta B, Pagès L, de Llorens R, de Bolòs C, Vidal-Vanaclocha F and Peracaula R: alpha2,3-sialyltransferase ST3Gal III modulates pancreatic cancer cell motility and adhesion in vitro and enhances its metastatic potential in vivo. PLoS One 5: pii: e12524, 2010.

55. Hsieh CC, Shyr YM, Liao WY, Chen TH, Wang SE, Lu PC, Lin PY, Chen YB, Mao WY, Han HY, et al: Elevation of $\beta$-galactoside $\alpha 2,6$-sialyltransferase 1 in a fructoseresponsive manner promotes pancreatic cancer metastasis. Oncotarget 8: 7691-7709, 2017.

56. Yue T, Goldstein IJ, Hollingsworth MA, Kaul K, Brand RE and Haab BB: The prevalence and nature of glycan alterations on specific proteins in pancreatic cancer patients revealed using antibody-lectin sandwich arrays. Mol Cell Proteomics 8: 1697-1707, 2009.

57. Park HM, Hwang MP, Kim YW, Kim KJ, Jin JM, Kim YH, Yang YH, Lee KH and Kim YG: Mass spectrometry-based $\mathrm{N}$-linked glycomic profiling as a means for tracking pancreatic cancer metastasis. Carbohydr Res 413: 5-11, 2015.

58. Zhao J, Qiu W, Simeone DM and Lubman DM: N-linked glycosylation profiling of pancreatic cancer serum using capillary liquid phase separation coupled with mass spectrometric analysis. J Proteome Res 6: 1126-1138, 2007.

59. Kamada Y, Kinoshita N, Tsuchiya Y, Kobayashi K, Fujii H, Terao N, Kamihagi K, Koyama N, Yamada S, Daigo Y, et al: Reevaluation of a lectin antibody ELISA kit for measuring fucosylated haptoglobin in various conditions. Clin Chim Acta 417: 48-53, 2013.

60. Barrabés S, Pagès-Pons L, Radcliffe CM, Tabarés G, Fort E, Royle L, Harvey DJ, Moenner M, Dwek RA, Rudd PM, et al: Glycosylation of serum ribonuclease 1 indicates a major endothelial origin and reveals an increase in core fucosylation in pancreatic cancer. Glycobiology 17: 388-400, 2007.

61. Fardini Y,Dehennaut V,Lefebvre Tand Issad T: O-GlcNAcylation: A new cancer hallmark? Front Endocrinol (Lausanne) 4: 99, 2013.

62. Bond MR and Hanover JA: A little sugar goes a long way: The cell biology of O-GlcNAc. J Cell Biol 208: 869-880, 2015

63. Liu Y, Cao Y, Pan X, Shi M, Wu Q, Huang T, Jiang H, Li W and Zhang J: O-GlcNAc elevation through activation of the hexosamine biosynthetic pathway enhances cancer cell chemoresistance. Cell Death Dis 9: 485, 2018.

64. Qian K, Wang S, Fu M, Zhou J, Singh JP, Li MD, Yang Y, Zhang K, Wu J, Nie Y, et al: Transcriptional regulation of O-GlcNAc homeostasis is disrupted in pancreatic cancer. J Biol Chem 293: 13989-14000, 2018.

65. Konrad RJ and Kudlow JE: The role of O-linked protein glycosylation in beta-cell dysfunction. Int J Mol Med 10: 535-539, 2002.

66. Ma Z, Vocadlo DJ and Vosseller K: Hyper-O-GlcNAcylation is anti-apoptotic and maintains constitutive NF- $\kappa \mathrm{B}$ activity in pancreatic cancer cells. J Biol Chem 288: 15121-15130, 2013.

67. Zachara NE, O'Donnell N, Cheung WD, Mercer JJ, Marth JD and Hart GW: Dynamic O-GlcNAc modification of nucleocytoplasmic proteins in response to stress. A survival response of mammalian cells. J Biol Chem 279: 30133-30142, 2004.

68. Banerjee S, Sangwan V, McGinn O, Chugh R, Dudeja V, Vickers SM and Saluja AK: Triptolide-induced cell death in pancreatic cancer is mediated by O-GlcNAc modification of transcription factor Sp1. J Biol Chem 288: 33927-33938, 2013.

69. Garg B, Giri B, Majumder K, Dudeja V, Banerjee S and Saluja A Modulation of post-translational modifications in $\beta$-catenin and LRP6 inhibits Wnt signaling pathway in pancreatic cancer. Cancer Lett 388: 64-72, 2017.

70. Sharma NS, Gupta VK, Dauer P, Kesh K, Hadad R, Giri B, Chandra A, Dudeja V, Slawson C, Banerjee S, et al: O-GlcNAc modification of oncogenic transcription factor Sox 2 promotes protein stability and regulates self-renewal in pancreatic cancer. bioRxiv: doi: https://doi.org/10.1101/345223.

71. Dwek RA, Butters TD, Platt FM and Zitzmann N: Targeting glycosylation as a therapeutic approach. Nat Rev Drug Discov 1: 65-75, 2002.

72. Vasconcelos-Dos-Santos A, Oliveira IA, Lucena MC, Mantuano NR, Whelan SA, Dias WB and Todeschini AR: Biosynthetic machinery involved in aberrant glycosylation: Promising targets for developing of drugs against cancer. Front Oncol 5: 138, 2015.

73. Iozzo RV and Sanderson RD: Proteoglycans in cancer biology, tumour microenvironment and angiogenesis. J Cell Mol Med 15: 1013-1031, 2011 
74. Pan S, Chen R, Stevens T, Bronner MP, May D, Tamura Y, McIntosh MW and Brentnall TA: Proteomics portrait of archival lesions of chronic pancreatitis. PLoS One 6: e27574, 2011.

75. Pan S, Chen R, Reimel BA, Crispin DA, Mirzaei H, Cooke K, Coleman JF, Lane Z, Bronner MP, Goodlett DR, et al: Quantitative proteomics investigation of pancreatic intraepithelial neoplasia. Electrophoresis 30: 1132-1144, 2009.

76. Chen R, Yi EC, Donohoe S, Pan S, Eng J, Cooke K, Crispin DA, Lane Z, Goodlett DR, Bronner MP, et al: Pancreatic cancer proteome: The proteins that underlie invasion, metastasis, and immunologic escape. Gastroenterology 129: 1187-1197, 2005.

77. Chen WB, Lenschow W, Tiede K, Fischer JW, Kalthoff $\mathrm{H}$ and Ungefroren H: Smad4/DPC4-dependent regulation of biglycan gene expression by transforming growth factor-beta in pancreatic tumor cells. J Biol Chem 277: 36118-36128, 2002.

78. Koninger J, Giese T, di Mola FF, Wente MN, Esposito I, Bachem MG, Giese NA, Büchler MW and Friess H: Pancreatic tumor cells influence the composition of the extracellular matrix. Biochem Biophys Res Commun 322: 943-949, 2004

79. Koninger J, Giese NA, di Mola FF, Berberat P, Giese T, Esposito I, Bachem MG, Büchler MW and Friess H: Overexpressed decorin in pancreatic cancer: Potential tumor growth inhibition and attenuation of chemotherapeutic action. Clin Cancer Res 10: 4776-4783, 2004.

80. Weber CK, Sommer G, Michl P, Fensterer H, Weimer M, Gansauge F, Leder G, Adler G and Gress TM: Biglycan is overexpressed in pancreatic cancer and induces G1-arrest in pancreatic cancer cell lines. Gastroenterology 121: 657-667, 2001.

81. Conejo JR, Kleeff J, Koliopanos A, Matsuda K, Zhu ZW, Goecke H, Bicheng N, Zimmermann A, Korc M, Friess H and Büchler MW: Syndecan-1 expression is up-regulated in pancreatic but not in other gastrointestinal cancers. Int J Cancer 88: 12-20, 2000.

82. Kleeff J, Ishiwata T, Kumbasar A, Friess H, Büchler MW, Lander AD and Korc M: The cell-surface heparan sulfate proteoglycan glypican-1 regulates growth factor action in pancreatic carcinoma cells and is overexpressed in human pancreatic cancer. J Clin Invest 102: 1662-1673, 1998.

83. Whipple CA, Young AL and Korc M: A KrasG12D-driven genetic mouse model of pancreatic cancer requires glypican-1 for efficient proliferation and angiogenesis. Oncogene 31 : 2535-2544, 2012.

84. Aikawa T, Whipple CA, Lopez ME, Gunn J, Young A, Lander AD and Korc M: Glypican-1 modulates the angiogenic and metastatic potential of human and mouse cancer cells. J Clin Invest 118: 89-99, 2008.

85. Melo SA, Luecke LB, Kahlert C, Fernandez AF, Gammon ST, Kaye J, LeBleu VS, Mittendorf EA, Weitz J, Rahbari N, et al: Glypican-1 identifies cancer exosomes and detects early pancreatic cancer. Nature 523: 177-182, 2015.
86. Ebrahim AH, Alalawi Z, Mirandola L, Rakhshanda R, Dahlbeck S, Nguyen D, Jenkins M, Grizzi F, Cobos E, Figueroa JA, et al: Galectins in cancer: Carcinogenesis, diagnosis and therapy. Ann Transl Med 2: 88, 2014.

87. Qian D, Lu Z, Xu Q, Wu P, Tian L, Zhao L, Cai B, Yin J, Wu Y, Staveley-O'Carroll KF, et al: Galectin-1-driven upregulation of SDF-1 in pancreatic stellate cells promotes pancreatic cancer metastasis. Cancer Lett 397: 43-51, 2017.

88. Zhao W, Ajani JA, Sushovan G, Ochi N, Hwang R, Hafley M, Johnson RL, Bresalier RS, Logsdon CD, Zhang $Z$ and Song S: Galectin-3 mediates tumor cell-stroma interactions by activating pancreatic stellate cells to produce cytokines via integrin signaling. Gastroenterology 154: 1524-1537.e6, 2018.

89. Chen R, Pan S, Ottenhof NA, de Wilde RF, Wolfgang CL, Lane Z, Post J, Bronner MP, Willmann JK, Maitra A and Brentnall TA: Stromal galectin-1 expression is associated with long-term survival in resectable pancreatic ductal adenocarcinoma. Cancer Biol Ther 13: 899-907, 2012.

90. Chen R, Dawson DW, Pan S, Ottenhof NA, de Wilde RF, Wolfgang CL, May DH, Crispin DA, Lai LA, Lay AR, et al: Proteins associated with pancreatic cancer survival in patients with resectable pancreatic ductal adenocarcinoma. Lab Invest 95: 43-55, 2015

91. Martinez-Bosch N, Fernández-Barrena MG, Moreno M, Ortiz-Zapater E, Munné-Collado J, Iglesias M, André S, Gabius HJ, Hwang RF, Poirier F, et al: Galectin-1 drives pancreatic carcinogenesis through stroma remodeling and Hedgehog signaling activation. Cancer Res 74: 3512-3524, 2014.

92. Orozco CA, Martinez-Bosch N, Guerrero PE, Vinaixa J, Dalotto-Moreno T, Iglesias M, Moreno M, Djurec M, Poirier F, Gabius HJ, et al: Targeting galectin-1 inhibits pancreatic cancer progression by modulating tumor-stroma crosstalk. Proc Natl Acad Sci USA 115: E3769-E3778, 2018.

93. Seguin L, Camargo MF, Wettersten HI, Kato S, Desgrosellier JS, von Schalscha T, Elliott KC, Cosset E, Lesperance J, Weis SM and Cheresh DA: Galectin-3, a druggable vulnerability for KRAS-addicted cancers. Cancer Discov 7: 1464-1479, 2017.

94. Bailey P, Chang DK, Nones K, Johns AL, Patch AM, Gingras MC, Miller DK, Christ AN, Bruxner TJ, Quinn MC, et al: Genomic analyses identify molecular subtypes of pancreatic cancer. Nature 531: 47-52, 2016

This work is licensed under a Creative Commons Attribution-NonCommercial-NoDerivatives 4.0 International (CC BY-NC-ND 4.0) License. 